\title{
Effects of Short-Term Exposure with Tri-n-Butyltin Chloride (TBTCl) and Bisphenol A on the Reproduction of the Striped Field Mouse
}

\author{
Ji-Hye Kim ${ }^{1}$, Byung-Yoon $\mathrm{Min}^{2}$ and Myung-Hee Yoon * \\ ${ }^{1}$ Department of Biology, Kyungsung University, Busan, 608-736, Korea \\ ${ }^{2}$ Division of Environmental Engineering, Kyungnam University, Masan, 631-701, Korea
}

Received December 1, 2010/Accepted March 10, 2011

\begin{abstract}
To investigate the effects of short-term treatment with tri-n-butyltin chloride (TBTCl) and bisphenol A (BPA) on the reproduction of striped field mice, the mice were intramuscularly injected with TBTCl or BPA immediately before the reproductive season and examined in the reproductive season after keeping them for 4 months. As a result, there were no differences between the control and the compound-treated groups regarding body weight in both sexes, the residual levels of the compounds in the adult males, and the gonadosomatic index (GSI) and the histological structures with LM and EM of the testes and epididymides in both the adult and young males. The infant mortality and abortion rate, however, were high in the TBTCl-treated groups and BPA-treated groups respectively, compared to the control group. Conclusively, it was suggested that short-term treatment with TBTCl or BPA in mice in the non-reproductive season might have inhibited the development of the uterine embryos or fetuses, although it did not induce accumulations of these compounds or affect the reproductive organs of adult and young (F1) males.
\end{abstract}

Key words : Bisphenol A, infant mortality, gonadosomatic index (GSI), reproductive organ, tri-n-butyltin chloride (TBTCl)

서 론

내분비계장애물질로 알려져 있는 비스페놀 $\mathrm{A}(\mathrm{BPA})$ 는 플 라스틱인 폴리카보네이트와 에폭시 수지의 합성원료로서 캔 용기의 코팅제와 치아의 보충제 등으로 사용되며, 고압과 열 을 가하는 산업 공정 등에 의해 유출되어 식품 등을 오염시킨 다고 알려져 있다[3]. 또 다른 내분비계장애물질인 유기주석 화합물은 주로 선박이나 어망, 어구 등의 방오제 등에 사용되 는데[6,8], 주로 해수 중에서 검출되며[15], 오염된 어패류 등을 통해 상위소비자에게까지 영향을 미치게 된다.

본 연구자들은 부산광역시 가덕도 대항동, 남해군 삼동면 및 산청군 지리산에서 1998년부터 2001년에 걸쳐 포획한 일부 등줄쥐에서 높은 농도의 페놀화합물(4-t-octylphenol, nonylphenol 및 $\mathrm{BPA}$ )과 유기주석화합물(monobutyltin, MBT; dibutyltin, DBT; tributyltin, TBT)을 검출하였으며, 이들 등줄쥐 의 대부분에서 생식소중량지수(GSI) 및 정소나 부정소 조직에 이상이 관찰된 점으로부터, 등줄쥐의 번식 이상이 페놀화합물 이나 유기주석 화합물의 영향에 의한 것이라고 추론한 바 있 다[10]. 본 연구에서는 위 연구에서 검출된 화합물 중 $\mathrm{TBTCl}$ 및 $\mathrm{BPA}$ 를 등줄쥐에 단기간 투여하여, 이들 화합물에 의한 단 기 노출이 등줄쥐의 생식기관에 미치는 영향 및 다음 세대의

*Corresponding author

Tel: +82-51-663-4642, Fax: +82-51-663-4645

E-mail: yhyun@ks.ac.kr
출생과 번식에 미치는 영향에 대해서 알아보고자 하였다.

\section{재료 및 방법}

\section{등줄쥐 채집}

번식 이상이 발생하지 않은 등줄쥐를 포획하기 위해서 주위 에 생활 및 공업형 오염원이 없는 경기도 이천시 설성면의 농경지 부근을 포획장소로 선정하여, 등줄쥐 수컷 약 40 개체 를 등줄쥐의 번식기 동안 Sherman live trap으로 포획하여 이 들의 생식소(정소 및 부정소)의 크기를 관찰한 결과 모두 정상 적인 크기의 생식소(GSI 3.0 이상)를 가지고 있었다. 따라서 위 장소에서 등줄쥐를 비번식기인 2002년 11월 2003년 2월에 걸쳐서 포획하여, 이 중 체중 $20 \mathrm{~g}$ 이상의 성체([21]참조) 암·수 각각 31 개체씩을 투여실험에 이용하였다. 등줄쥐는 포획 직 후, 실험실로 옮겨와서 일주일간 순화시키고, 교미율을 높이 기 위해 수컷 한 개체 당 각 수컷의 체중보다 약 $1 \sim 2 \mathrm{~g}$ 정도 가벼운 체중의 암컷을 선별하여, 투여 실험 직전까지 약 1 3 개월 동안 암.수 한 쌍씩 사육용 케이지에 넣어 실외에서 사육 하였다. 사육용 사료와 물은 충분히 공급하였으며, 신선한 야 채와 과일 등을 수시로 공급하여 스트레스를 최소화하였다. 야 생 등줄쥐의 사육은 Oh와 Mori [14]의 방법을 참고로 하였다.

TBTCl과 Bisphenol A의 투여

본 연구에 사용된 $\mathrm{TBTCl}$ (tri-n-butyltin chloride)은 동경화 
성공업주식회사로부터 구입한 순도 $95 \%$ 의 화합물이며, BPA 는 Aldrich사에서 구입한 순도 $99 \%$ 의 화합물로서, 이들을 com oil (Sigma사)에 녹여 사용하였다. 시료 준비를 위해 사용 한 모든 초자기구는 증류한 아세톤과 헥산으로 3 회씩 세척한 후 완전히 건조시켜 사용하였다.

암 - 수 15 쌍의 비번식기 등줄쥐를 5쌍씩 세 그룹 즉, TBTCl 300,600 및 3,000 $\mathrm{\mu g} / \mathrm{kg} / \mathrm{day}$ 투여군으로 나누어 실험군별로 번식기 직전인 2003년 2월 말부터 7일간 해당 농도의 TBTCl을 대퇴부에 근육주사 하였다. 또 다른 암.수 12 쌍의 등줄쥐를 암.수 4쌍씩 3 그룹, 즉 BPA 250, 500 및 $5,000 \mu \mathrm{g} / \mathrm{kg} / \mathrm{day}$ 투여군으로 나누어 2월 말부터 7일간 위와 같은 방법으로 주 사하였다. 대조군 4 쌍에게는 corn oil $10 \mathrm{ml} / \mathrm{kg} / \mathrm{day}$ 씩을 동일 한 방법으로 주사하였다. 각 화합물의 투여 농도는 각 화합물 의 대사율(TBTCl, [17,20]; $\mathrm{BPA},[1])$, 야생 등줄쥐에서의 검출 된 양[10] 및 여러 연구에서 실험용 흰쥐에 투여한 양[15,16]을 근거로 설정하였다. 화합물의 투여가 끝난 2003년 3월부터 이 들에게 사육용 사료와 물을 충분히 공급하면서 번식 활성기인 6월말까지([21]참조) 4개월간 사육한 후, 수컷 등줄쥐(부모세 대)의 생식소중량지수(GSI, gonadosomatic index, 체중에 대 한 오른쪽 정소 및 부정소의 무게 비), 정소 및 부정소의 광학 및 전자현미경상, 각 화합물의 체내 잔류농도, 이들로부터 태 어난 F1세대들의 개체 수, 수컷 새끼들이 성체에 이르렀을 때 의 생식소중량지수, 정소 및 부정소 조직의 광학 및 전자현미 경상을 조사하였다. 모든 실험군와 대조군과의 유의차는 t-test 를 사용하여 검정하였다.

\section{$\mathrm{TBTCl}$ 및 $\mathrm{BPA}$ 의 잔류농도 측정}

실험 종료 후 $\mathrm{TBTCl}$ 및 $\mathrm{BPA}$ 를 투여한 실험군들로부터 조 직학적 관찰을 위해 오른쪽 정소 및 부정소를 적출하고, 나머 지 시료는 분석을 위하여 냉동 $\left(-70^{\circ} \mathrm{C}\right)$ 시켰다. 이후 분석을 위
하여 모든 시료를 일본 에히메 대학의 환경과학연구소 (Laboratory of Environmental Science)로 보내어, 일본 환경 성[11]에 명기된 방법에 의하여 $\mathrm{TBTCl}$ 및 $\mathrm{BPA}$ 의 잔류 농도를 분석하였다. 분석 조건 및 실험방법은 Table 1 에 제시하였다. 각 시료를 균질화 하여, 이 중 $3 \sim 5 \mathrm{~g}$ (습중량)의 시료를 취한 후, 각각 검출하고자 하는 화합물질에 대한 적절한 유기용매 를 사용하여 화합물을 추출하고, florisil-column으로 세정한 후, 가스크로마토그래피(6890 GC, 5973MSD; Agilent Technologies)를 이용하여 분석하였다. 검출한계는 0.1 6 $\mathrm{ng} / \mathrm{g}$ 이었으며, 회수율은 $67 \sim 108 \%$ 였다.

\section{조직학적 관찰}

등줄쥐로부터 적출한 오른쪽 정소 및 부정소를 $1 \mathrm{~mm}^{3}$ 의 크기로 세절하여 $2 \%$ paraformaldehyde와 $2.5 \%$ glutaraldehyde의 혼합고정액 $(\mathrm{pH}$ 7.4)에서 24시간 전고정한 후, $1.3 \% \mathrm{OsO}_{4}$ 로 1 시간 30 분 동안 후고정하였다. 이후 알콜 탈수 와 아세톤 치환과정을 거쳐 epon 812 혼합액으로 포매 중합하 였다. 초미세 박절기(LKB2088)로 $10 \mu \mathrm{m}$ 정도의 두께로 자른 후 $0.5 \%$ toluidine blue로 염색하여 광학현미경으로 관찰하였 고, 60 90 nm의 두께로 잘라 uranyl acetate와 lead citrate로 이중 염색하여 투과전자현미경(JEOL100s)으로 관찰하였다.

\section{결 과}

$\mathrm{TBTCl}$ 과 $\mathrm{BPA}$ 의 단기투여가 체중에 미치는 영향을 알아보 기 위하여 투여 개시부터 실험 종료까지 약 4 개월간의 체중의 증가량을 비교한 결과 암·수 모두 대조군과 유의적인 차이를 나타내지 않았다(Table 2).

$\mathrm{TBTCl}$ 과 $\mathrm{BPA}$ 투여실험 종료 후 유기주석 화합물(MBT, $\mathrm{DBT}$ 및 TBT)과 BPA의 수컷 체내 잔류 농도는 TBTCl $300 \mu \mathrm{g} /$

Table 1. Analytical methods of endocrine-disrupting chemicals, limits of quantitation, and average recoveries from each of the chemicals

\begin{tabular}{|c|c|c|c|c|}
\hline Chemicals analyzed & $\begin{array}{c}\text { Limit of } \\
\text { quantification }(\mathrm{ng} / \mathrm{g})\end{array}$ & $\begin{array}{l}\text { Recovery } \\
(\text { mean, \%) }\end{array}$ & $\begin{array}{l}\text { Extraction solvent } \\
\text { sample taken }(\mathrm{g})\end{array}$ & Purification method \\
\hline \multicolumn{5}{|l|}{ Phenol compounds } \\
\hline 4-n-Heptylphenol & 1 & 113 & \multirow{5}{*}{ Methanol $5 \mathrm{~g}$} & \multirow{5}{*}{$\begin{array}{l}\text { Methanol partition } \\
\text { Derivatization using diethyl } \\
\text { sulfate Florisil column GPC }\end{array}$} \\
\hline $\begin{array}{l}\text { 4-t-Butylphenol, 2,4-Dichlorophenol, } \\
\text { 4-n-Octylphenol, 4-n-Hexylphenol }\end{array}$ & 0.2 & $77-127$ & & \\
\hline $\begin{array}{l}\text { 4-n-Pentylphenol, Pentachlorophenol, } \\
\text { Bisphenol A }\end{array}$ & 0.4 & $86-108$ & & \\
\hline 4-t-Octylphenol & 0.1 & 108 & & \\
\hline Nonylphenol & 6 & 109 & & \\
\hline \multicolumn{5}{|l|}{ Organotin compounds } \\
\hline Monobutyltin & 2 & & \multirow{4}{*}{$\begin{array}{l}0.1 \% \text { Tolopolone/ } \\
\text { Acetone } 5 \mathrm{~g}\end{array}$} & \multirow{4}{*}{$\begin{array}{l}\text { Derivatization using } \\
\text { n-propylmagnesium bromide } \\
\text { Florisil column GPC }\end{array}$} \\
\hline Dibutyltin & 6 & & & \\
\hline Tributyltin & 0.1 & 67 & & \\
\hline Triphenyltin & 0.2 & 102 & & \\
\hline
\end{tabular}


Table 2. Comparisons of the increased body weight $(\mathrm{g})$ during about four months since the treatment with TBTCl and BPA

\begin{tabular}{|c|c|c|c|c|c|c|c|}
\hline \multirow{2}{*}{ Compounds } & \multicolumn{3}{|c|}{ TBTCl $(\mu \mathrm{g} / \mathrm{kg} /$ day $)$} & \multicolumn{3}{|c|}{ BPA（ $\mu g / k g /$ day $)$} & \multirow{2}{*}{$\begin{array}{c}\text { Corn oil }(\mathrm{ml} / \mathrm{kg} / \text { day }) \\
10\end{array}$} \\
\hline & 300 & 600 & 3000 & 250 & 500 & 5000 & \\
\hline Male & $\begin{array}{c}6.23 \pm 3.63 \\
\quad(\mathrm{~N}=5)\end{array}$ & $\begin{array}{c}9.55 \pm 3.56 \\
(\mathrm{~N}=4)\end{array}$ & $\begin{array}{c}7.75 \pm 4.52 \\
(\mathrm{~N}=5)\end{array}$ & $\begin{array}{l}6.31 \pm 5.61 \\
\quad(\mathrm{~N}=4)\end{array}$ & $\begin{array}{l}5.70 \pm 0.86 \\
\quad(\mathrm{~N}=3)\end{array}$ & $\begin{array}{c}7.86 \pm 2.85 \\
(\mathrm{~N}=4)\end{array}$ & $\begin{array}{l}6.74 \pm 3.33 \\
\quad(\mathrm{~N}=4)\end{array}$ \\
\hline Female & $\begin{array}{c}3.79 \pm 1.72 \\
\quad(\mathrm{~N}=4)\end{array}$ & $\begin{array}{c}6.32 \pm 1.80 \\
\quad(\mathrm{~N}=4)\end{array}$ & $\begin{array}{c}4.68 \pm 5.30 \\
(\mathrm{~N}=4)\end{array}$ & $\begin{array}{c}5.41 \pm 2.35 \\
(\mathrm{~N}=4)\end{array}$ & $\begin{array}{c}5.63 \pm 3.52 \\
(\mathrm{~N}=4)\end{array}$ & $\begin{array}{c}8.04 \pm 5.10 \\
(\mathrm{~N}=4)\end{array}$ & $\begin{array}{c}5.25 \pm 4.64 \\
\quad(\mathrm{~N}=4)\end{array}$ \\
\hline
\end{tabular}

Table 3. GSI and residual levels of the compounds in the male striped field mice treated with TBTCl or BPA

\begin{tabular}{|c|c|c|c|c|c|}
\hline \multirow{2}{*}{\multicolumn{2}{|c|}{ Treated compounds }} & \multirow{3}{*}{$\begin{array}{c}\mathrm{GSI}^{*}(\%) \\
3.42 \pm 0.23\end{array}$} & \multicolumn{3}{|c|}{ Residual levels (ng/g wet) } \\
\hline & & & TBT & $\sum \mathrm{MBT}+\mathrm{DBT}$ & BPA \\
\hline \multirow{3}{*}{$\begin{array}{c}\text { TBTCl } \\
(\mu \mathrm{g} / \mathrm{kg} / \text { day })\end{array}$} & $300(\mathrm{~N}=5)$ & & $10.85 \pm 2.36^{\dagger, * *}$ & $59.41 \pm 81.97^{\dagger}$ & - \\
\hline & $600(\mathrm{~N}=4)$ & $3.22 \pm 0.61$ & $13.67 \pm 12.31$ & $9.52 \pm 6.05$ & - \\
\hline & $3000(\mathrm{~N}=5)$ & $3.26 \pm 0.17$ & $9.38 \pm 16.40$ & $30.40 \pm 32.46$ & - \\
\hline \multirow{3}{*}{$\begin{array}{c}\text { BPA } \\
(\mu \mathrm{g} / \mathrm{kg} / \text { day })\end{array}$} & $250(\mathrm{~N}=4)$ & $3.00 \pm 0.66$ & & - & $4.63 \pm 7.17$ \\
\hline & $500(\mathrm{~N}=3)$ & $3.46 \pm 0.05$ & & - & $1.58 \pm 2.28$ \\
\hline & $5000(\mathrm{~N}=4)$ & $3.12 \pm 0.37$ & & - & $19.28 \pm 17.25$ \\
\hline $\begin{array}{c}\text { Corn oil } \\
(\mathrm{ml} / \mathrm{kg} / \text { day })\end{array}$ & $10(\mathrm{~N}=4)$ & $3.21 \pm 0.69$ & $0.20 \pm 0.26$ & $30.08 \pm 30.51$ & $3.66 \pm 3.83$ \\
\hline
\end{tabular}

${ }^{*}$ Gonadosomatic index

${ }^{* *} p<0.01$

${ }^{\dagger}$ The level was based on only three individuals.

$\mathrm{kg} / \mathrm{day}$ 투여군에서 TBT가 대조군에 비해 높은 농도로 검출되 었으나, 나머지 실험군에서는 대조군과 유의적인 차이를 보이 지 않았고(Table 3), 생식소중량지수(GSI)는 모든 실험군에서 평균 3.0\% 이상 $(3.00 \% 3.46 \%)$ 으로써, 대조군(3.21\%)과 유의적 인 차이를 보이지 않았다. 수컷의 정소 내 생식세포들은 정상 적인 정자형성과정을 나타내고 있었고, 지지세포의 핵, 세포 막 등도 대조군과의 사이에서 차이점을 나타내지 않았다(Fig. 1). 또한, 부정소 내의 정자의 첨체, 미토콘드리아 및 세포막 등의 미세구조에서도 이상은 발견되지 않았다.

암컷의 임신비율은 양 화합물 투여군 모두 대조군보다 약간 낮은 비율을 나타내었으나 유의적인 차이는 없었다(Table 4). 즉 대조군의 경우 암컷 4 개체 중 1 개체 $(\mathrm{CON}-2)$ 가 1 회 임신에 성공하였으나(평균 임신율 25\%), TBTCl 투여군에서는 $300 \mu$ $\mathrm{g} / \mathrm{kg} / \mathrm{day}$ 투여군 암컷 5 개체(T300-1 5) 중 2개체(T300-2,-4) 와 3,000 $\mu \mathrm{g} / \mathrm{kg} / \mathrm{day}$ 투여군 암컷 5개체(T3000-1 5) 중 1 개체 (T3000-2)가 각각 2회씩의 임신에 성공하였고 $(040 \%$, 평균 임 신율 20\%), BPA $500 \mu \mathrm{g} / \mathrm{kg} / \mathrm{day}$ 투여군 암컷 4개체(B500-1 4) 및 5,000 $\mu \mathrm{g} / \mathrm{kg} / \mathrm{day}$ 투여군 4개체(B5000-1 4) 중에서는 각각 1 개체씩(B500-4, B5000-3)이 임신에 성공하여 이들의 임신율 (0 25\%, 평균 $17 \%)$ 은 대조군보다 약간 낮았다.

한편 출산율 및 새끼(F1)의 생존율은 양 화합물 투여군 모두 대조군보다 현저히 낮았고, 특히 BPA투여군의 생존율(0 67\%, 평균 $17 \%)$ 은 $\mathrm{TBTCl}$ 투여군의 생존율( 67 100\%, 평균 87\%)에 비해 현저히 낮았다. 즉 $\mathrm{TBTCl}$ 투여군의 경우, $300 \mu \mathrm{g} / \mathrm{kg} / \mathrm{day}$ 투여군 중 임신한 T300-2개체는 2회에 걸쳐 7개체(주웅)의 새끼를 낳아 모두 살아 남았고, T300-4 개체의 경우도 2회에
걸쳐 7개체의 새끼를 낳았으나, 한 마리가 어미에게 먹혀 6개 체(35:우1)가 살아남았다. TBTCl 3,000 $\mu \mathrm{g} / \mathrm{kg} / \mathrm{day}$ 투여군 중 T3000-2 개체의 경우 첫 회 태어난 6개체와 두 번째 태어난 3 개체 중 각각 1 개체씩이 죽어 어미에게 먹혔고 7 개체(궁ㅇ 3 ) 만이 생존했다. BPA 투여군 중 $250 \mu \mathrm{g} / \mathrm{kg} / \mathrm{day}$ 를 투여한 4개 체는 모두 임신에 실패했고, $500 \mu \mathrm{g} / \mathrm{kg} / \mathrm{day}$ 를 투여한 B500-4 개체는 임신에는 성공했지만 출산에 실패하였고(14개의 자궁 내 배아 확인), $5,000 \mu \mathrm{g} / \mathrm{kg} / \mathrm{day}$ 를 투여한 B5000-3개체의 경 우는 첫 회 출산 시 태어난 6 개체 중 2 개체가 출산 즉시 죽어 4개체가 생존했고(1:우3), 두 번째 수태된 개체들은 모두 유산 되어(4개의 자궁 내 배아 확인), 새끼의 생존율이 $\mathrm{TBTCl}$ 투여 군 보다 더 낮았다.

한편, 수컷 새끼들이 성 성숙한 후 측정한 생식소중량지수 는 3.34 4.44\% (N=16)로써 대조군에서 태어난 수컷 새끼의 생식소중량지수 $(3.16 \%, 2.93 \%, \mathrm{~N}=2)$ 와 유의적인 차이를 나 타내지 않았다(Table 4). 더욱이 F1세대 수컷 생식소의 광학 및 전자현미경상도 투여군과 대조군 사이에 차이가 보이지 않았다.

\section{고 찰}

본 연구 결과 $\mathrm{TBTCl}$ 및 $\mathrm{BPA}$ 의 단기 투여는 농도에 상관없 이 등줄쥐 성체 및 새끼 $(\mathrm{F} 1)$ 수컷의 생식소중량지수나 생식소 의 미세구조에 영향을 미치지 않음이 밝혀졌고, 실험용 흰쥐 나 생쥐에서도 이들 화합물의 단기 투여에 의해서 번식에 이 상이 발생하지 않음이 보고된 바 있다. 즉, 수컷 흰쥐에게 
Table 4. Comparisons of the rates of pregnancy, survived offsprings, and the GSI of the male mice in the F1 generation between the TBTCl and BPA treated groups, and the control group

\begin{tabular}{|c|c|c|c|c|c|c|c|c|}
\hline \multirow{2}{*}{\multicolumn{2}{|c|}{ Compounds }} & \multirow{3}{*}{$\begin{array}{c}\text { No. } \\
\text { females }\end{array}$} & \multirow{3}{*}{$\begin{array}{c}\text { Pregnant Females } \\
\begin{array}{c}\text { (rate of } \\
\text { pregnancy, \%) }\end{array} \\
1(25)\end{array}$} & \multirow{3}{*}{$\begin{array}{c}\begin{array}{c}\text { Individual no. of } \\
\text { pregnant } \\
\text { females }\end{array} \\
\mathrm{CON}-2\end{array}$} & \multirow{3}{*}{$\begin{array}{c}\begin{array}{c}\text { Count of } \\
\text { conception } \\
\text { oberved }\end{array} \\
1 \\
\end{array}$} & \multicolumn{3}{|c|}{ Offspring } \\
\hline & & & & & & \multirow{2}{*}{$\begin{array}{c}\begin{array}{c}\text { Survived } \\
(\text { survival rate } \%, \mathrm{M} / \mathrm{F})\end{array} \\
6(100,2 / 4)\end{array}$} & \multirow{2}{*}{$\begin{array}{c}\text { Died } \\
0 \\
\end{array}$} & \multirow{2}{*}{$\begin{array}{l}\mathrm{GSI}^{*}(\%) \\
3.16,2.93 \\
\end{array}$} \\
\hline $\begin{array}{c}\text { Corn oil } \\
\text { (ml/kg/day) }\end{array}$ & 10 & & & & & & & \\
\hline \multirow{7}{*}{$\begin{array}{c}\text { TBTCl } \\
\text { ( } \mathrm{\mu g} / \mathrm{kg} / \text { day })\end{array}$} & \multirow{4}{*}{300} & \multirow{4}{*}{5} & \multirow{4}{*}{$2(40)$} & \multirow{2}{*}{ Т300-2 } & \multirow{2}{*}{2} & $4(100,2 / 2)$ & 0 & $3.46,3.34$ \\
\hline & & & & & & $3(100,2 / 1)$ & 0 & $3.65,3.52$ \\
\hline & & & & \multirow{2}{*}{ Т300-4 } & \multirow{2}{*}{2} & $3(75,3 / 0)$ & $1^{* *}$ & $3.93-4.29$ \\
\hline & & & & & & $3(100,2 / 1)$ & 0 & $3.84,4.44$ \\
\hline & 600 & 5 & $0(0)$ & - & - & - & - & - \\
\hline & \multirow{2}{*}{3000} & \multirow{2}{*}{5} & \multirow{2}{*}{$1(20)$} & \multirow{2}{*}{ Т3000-2 } & \multirow{2}{*}{2} & $5(83,3 / 2)$ & $1^{* *}$ & $3.72-4.35$ \\
\hline & & & & & & $2(67,1 / 1)$ & $1^{* *}$ & 3.61 \\
\hline \multicolumn{2}{|c|}{ Total } & 15 & $3(20)$ & & 6 & $20(87,13 / 7)$ & 3 & $3.34-4.44$ \\
\hline \multirow{4}{*}{$\begin{array}{c}\text { BPA } \\
(\mu \mathrm{g} / \mathrm{kg} / \text { day })\end{array}$} & 250 & 4 & $0(0)$ & - & - & - & - & - \\
\hline & 500 & 4 & $1(25)$ & B500-4 & 1 & 0 & [14] & - \\
\hline & \multirow{2}{*}{5000} & \multirow{2}{*}{4} & \multirow{2}{*}{ 1(25) } & \multirow{2}{*}{ B5000-3 } & \multirow{2}{*}{2} & $4(67,1 / 3)$ & $2^{* *}$ & 4.38 \\
\hline & & & & & & 0 & {$[4]$} & - \\
\hline \multicolumn{2}{|c|}{ Total } & 12 & $2(17)$ & & 3 & $4(17,1 / 3)$ & $2+[18]$ & 4.38 \\
\hline
\end{tabular}

${ }^{*}$ Gonadosomatic index

${ }^{* *}$ Eaten by parents immediately after birth

[] Number of fetuses aborted

TBTCl $5 \mathrm{mg} / \mathrm{kg}$ 을 단기간(10일) 투여했을 경우 생식소에 별다 른 이상이 나타나지 않았다고 보고되어 있으며[22], 수컷 생쥐 와 흰쥐에게 각각 $0.1,1,5,10 \mathrm{\mu g} / \mathrm{mouse}$ 와 $1,10,100,600$ $\mathrm{\mu g} / \mathrm{rat}$ 의 $\mathrm{BPA}$ 를 12 일 동안 격일로 주사한 후 15 일째에 관찰한 결과 정세포의 첨체와 핵의 형태적 이상이 성 성숙 시기에 모두 정상으로 회복되었다고 보고되어 있다[18]. 또한 $300 \mu \mathrm{g} /$ $\mathrm{g}$ 의 $\mathrm{BPA}$ 를 출산 직후의 수컷 흰쥐에게 5 일 동안 투여한 경우 에도 성 성숙시기 이후의 생식소에 별다른 이상이 관찰되지 않았다[12]. 이러한 연구 결과들로부터 등줄쥐도 생쥐나 흰쥐 와 유사하게 $\mathrm{TBTCl}$ 이나 $\mathrm{BPA}$ 의 단기 투여에 의해서 영향을 받지 않음을 알 수 있다. 이러한 결과는 $\mathrm{TBTCl}$ 이나 $\mathrm{BPA}$ 의 등줄쥐 체내에서의 빠른 대사 속도와도 연관이 있는 것으로 생각되는데(Table 3), 포유류에서는 투여방법에 관계없이 $\mathrm{BPA}$ 는 대변(56 82\%)으로, BPA의 대사산물은 소변(13 28\%) 을 통해서 대부분 배설된다고 알려져 있다[9]. Tanabe 등[17] 과 Watanabe 등[20]도 해양포유류와 비교해서 육상포유류에 서 유기주석 화합물이 낮게 검출되는 이유를 이들의 대사활성 이 해양포유류보다 훨씬 높기 때문이라고 보고하고 있다. 본 연구에서도 $\mathrm{TBTCl}$ 과 $\mathrm{BPA}$ 투여 후 4 개월 후의 잔류 농도가 대조군과 대부분 유의차를 보이지 않아 투여된 화합물이 4 개 월 이내에 대부분 대사된 것으로 생각되었다.

한편 수컷 생쥐에게 $0.5,5,50 \mu \mathrm{g} / \mathrm{kg}$ 의 TBT를 장기간(성성 숙 개시기부터 30 일 동안) 투여했을 경우 모든 투여군에서 생 식소중량지수가 뚜렷이 감소하고, 정자형성과정에서도 이상
이 나타났으며[5], $0.5,15 \mathrm{mg} / \mathrm{kg}$ 의 TBT를 30일 동안 투여했을 경우에도 부정소, 전립선 및 정낭무게의 감소가 나타났음이 보고되어 있다[7]. 또한 수컷 생쥐에게 BPA $50 \mu \mathrm{g} / \mathrm{ml}$ 를 8주간 투여했을 때, testosteron이 감소하고 정세관에서 거핵세포가 관찰되었으며[16], 수컷 흰쥐에게 수유기부터 성 성숙시기까 지 1 달간 $100 \mathrm{mg} / \mathrm{kg}$ 의 BPA를 투여했을 경우 성 성숙시기가 지연되고 정자형성과정에 영향을 준다는 연구도 있다[2]. 즉 $\mathrm{TBT}$ 나 $\mathrm{BPA}$ 에 장기간 노출되었을 때는 흰쥐의 번식이 방해되 는 것을 알 수 있는데, 이러한 연구결과들로부터 등줄쥐에서 도 $\mathrm{TBT}$ 나 $\mathrm{BPA}$ 에 장기간 노출될 경우 이들 화합물이 등줄쥐의 번식에 영향을 미칠 가능성을 배제할 수는 없다. 따라서 서론 에서 언급한 Kim 등[10]의 연구에서 보고된 야생 등줄쥐의 낮은 생식소중량지수 비율이나 정소와 부정소의 조직 이상 현상이 이들 화합물에 의해서 유발된 현상이라면 아마도 이들 화합물에 장기간 노출된 결과일 것으로 생각된다.

한편, TBTCl과 BPA의 단기투여는 $\mathrm{F} 1$ 세대의 태아 발생에 크게 영향을 미침이 밝혀졌다. 즉, 양 화합물의 투여군(BPA 투여군의 태아 생존율, 0 67\%, 평균 17\%; TBTCl 투여균의 태 아 생존율, 67 100\%, 평균 87\%)에서는 대조군(태아 생존율, $100 \%$ )에 비해서 태아의 생존율이 낮고 임신 후 유산된 개체 (B500-4, B5000-3)가 많았으며, cannibalism의 가능성을 배제 할 순 없지만 출산 후 어미에 의해 먹힌 예(T300-4, T3000-2, B5000-3)가 많았다(Table 4). 이러한 결과는 tri-n-butyltin acetate가 흰쥐에서 태아의 사망률을 증가시키고[13], $200 \mu \mathrm{g}$ / 


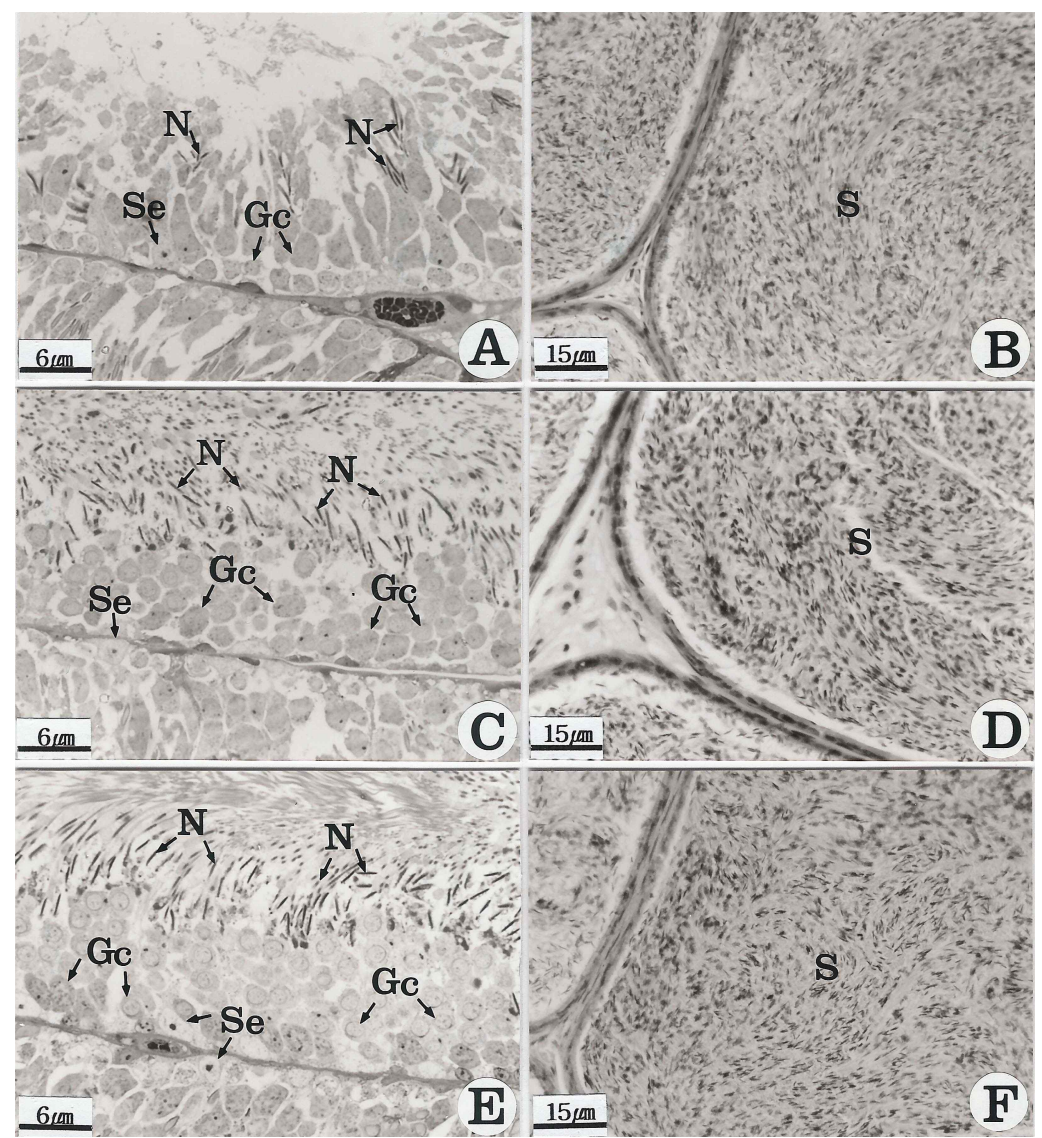

Fig. 1. Light micrographs of the reproductive organs in the striped field mice exposed to corn oil (A, B), TBTCl 3,000 $\mu \mathrm{g} / \mathrm{kg} / \mathrm{day}$ (C, D) and BPA 5,000 $\mathrm{\mu g} / \mathrm{kg} / \mathrm{day}$ (E, F), showing normal abundant spermatogenic germ cells and spermatozoa in the enlarged seminiferous (A, C and E) and epididymal tubules (B, D and F). Gc, germ cell; S, intact spermatozoa; Se, Sertoli cell; N, nucleus.

$\mathrm{kg} / \mathrm{day}$ 의 BPA를 투여한 어미 생쥐에서 태어난 한 배 새끼의 수가 대조군에 비해 비교적 적었으며[4], 7,500 ppm의 BPA를 투여한 어미 흰쥐에서 태어난 새끼들에서의 사망률이 높았다 는 연구[19]와 매우 유사하다.

결론적으로, $\mathrm{TBTCl}$ 및 $\mathrm{BPA}$ 를 비번식기의 성체 등줄쥐에게 고농도 또는 저농도로 단기간 투여했을 때, 이들 화합물은 체 내에 장기간 잔류하지 않으며, 부모세대와 F1세대의 생식소중 량지수 및 정소와 부정소 조직에 영향을 미치지 않으나, 고농 도의 $\mathrm{TBTCl}$ 또는 $\mathrm{BPA}$ 의 투여에 의해 유산율이 높아지고 태아 의 수태율 및 생존율이 낮아지는 점으로부터 양 화합물이 태 아의 발생에는 영향을 미칠 수 있음이 시사되었다. 한편 이들 화합물을 등줄쥐에게 장기간 노출시 등줄쥐의 번식에 영향을 미칠 가능성을 배제할 수 없으므로, 앞으로 장기간의 노출 시 험을 통하여 이들 화합물이 번식에 미치는 영향을 규명하여야 할 것이다.

\section{감사의 글}

이 논문은 2011 학년도 경성대학교 학술연구비지원에 의해
연구되었습니다.

\section{References}

1. Alfonza, A. and R. Deodutta. 1995. In vitro conversion of environmental estrogenic bisphenol A to DNA binding metabolite(s). Biochem. Biophys. Res. Commun. 210, 424-433.

2. Benjamin, L. L., N. M. Kassim, and M. A. Mohd. 2003. Assessment of pubertal development in juvenile male rats after sub-acute exposure to bisphenol A and nonylphenol. Toxicol. Lett. 143, 261-270.

3. Brotons, J. A., M. F. Oleaserrano, M. Villalobos, V. Pedraza and N. Olea. 1995. Xenoestrogens released from lacquer coatings in food cans. Environ. Health Perspect. 103, 608-612.

4. Butala, J. H., S. Z. Cagen, J. M. Waechter, S. S. Dimond, W. J. Breslin, F. W. Jekat, R. L. Joiner, R. N. Shiotsuka, G. E. Veenstra, and L. R. Harris. 2001. Normal reproductive organ development in $\mathrm{CF}^{-1}$ mice following prenatal $\mathrm{ex}^{-}$ posure to bisphenol $\mathrm{A}$ and in wistar rats exposed to $\mathrm{bi}^{-}$ sphenol A in the drinking water. Proc. Reprod. Toxicol. 15, 587-599. 
5. Chen, Y., Z. Zuo, S. Chen, F. Yan, Y. Chen, Z. Yang, and C. Wang. 2008. Reduction of spermatogenesis in mice after tributyltin administration. Toxicol. 29, 21-27.

6. Fent, K. 1996. Ecotoxicology of organotin compounds. Crit. Rev. Toxicol. 26, 1-117.

7. Grote, K., B. Stahlschmidt, C. E. Talsness, C. Gericke, K. E. Appel, and I. Chahoud. 2004. Effects of organotin compounds on pubertal male rats. Toxicol. 202, 145-158.

8. Hashimoto, S., M. Watanabe, Y. Noda, T. Hayashi, Y. Kurita, Y. Takasu, and A. Otsuki. 1998. Concentration and distribution of butyltin compounds in a heavy tanker route in the strait of malacca and in Tokyo bay. Mar. Environ. Res. 45, 169-177.

9. Kang, J. H., K. Yoshiki, and K. Fusao. 2006. Biodegradation or metabolism of bisphenol A: From microorganisms to mammals. Toxicol. 217, 81-90.

10. Kim, J. H., M. H. Yoon, Y. Ueda, K. Honda, and B. Y. Min. 2006. Relationships between the abnormalities of the male reproductive organs and the accumulation of phenol compounds in the striped field mouse, Apodemus agrarius, inhabiting Korea. Environ. Pollut. 144, 716-725.

11. Ministry of Environment. 1998. Manual on analysis and determination of endocrine disruptors in water, sediment and organism. Japan.

12. Nagao, T., Y. Saito, K. Usumi, M. Kuwagata, and K. Imai. 1999. Reproductive functions in rats exposed neonatally to bisphenol A and estradiol benzoate. Reprod. Toxicol. 13, 303-311.

13. Noda, T., S. Morita, T. Yamano, M. Shimizu, T. Nakamura, M. Saitoh, and A. Yamada. 1991. Teratogenicity study of tri-n-butyltin acetate in rats by oral administration. Toxicol. Lett. 55, 109-115.

14. Oh, H. S. and Mori T. 1998. Reproduction, growth and development of the Korean striped mouse, Apodemus agrarius chejuenesis. Mammalian Sci. 38, 23-37.

15. Takahashi, S., S. Tanabe, I. Takeuchi, and N. Miyazaki. 1999. Distribution and specific bioaccumulation of butyltin compounds in a marine ecosystem. Arch. Environ. Contam. Toxicol. 37, 50-61.

16. Takao, T., W. Nanamiya, I. Nagano, K. Asaba, K. Kawabata, and K. Hashimoto. 1999. Exposure with the environmental estrogen bisphenol A disrupts the male reproductive tract in young mice. Life Sci. 65, 2351-2357.

17. Tanabe, S., S. Watanabe, H. Kan, and R. Tatsukawa. 1988. Capacity and mice of PCB metabolism in small cetaceans. Mar. Mam. Sci. 4, 103-124.

18. Toyama, Y. and S. Yuasa. 2004. Effects of neonatal administration of $17 \beta$-estradiol, $\beta$-estradiol 3 -benzoate, or bisphenol A on mouse and rat spermatogenesis. Reprod. Toxicol. 19, 181-188.

19. Tyl, R. W., C. B. Myers, M. C. Marr, T. Y. Chang, J. C. Seely, D. R. Brine, M. M. Veselica, P. A. Fail, R. L. Joiner, J. H. Butala, S. S. Dimond, R. N. Shiotsuka, G. Stropp, G. E. Vednstra, J. M. Waechter, and L. R. Harris. 2001. Three-generation reproductive toxicity study of bisphenol A (BPA) administered in the diet to $\mathrm{CD}$ (Sprague-Dawley) rats. Proceeding / Reprod. Toxicol. 15, 587-599.

20. Watanabe, S., T. Shimada, S. Nakamura, N. Nishiyama, N. Yamashita, S. Tanabe, and R. Tatsukawa. 1989. Specific profile of liver microsomal cytochrome $\mathrm{P}-450$ in dolphin and whales. Mar. Environ. Res. 27, 51-56.

21. Yoon, M. H., S. J. Jung, and H. S. Oh. 1997. Population structure and reproduction pattern of the Korean striped field mouse, Apodemus agrarius. Korean J. Biol. Sci. 1, 53-61.

22. Yu, W. J., S. Y. Nam, Y. C. Kim, B. J. Lee, and Y. W. Yun. 2003. Effects of tributyltin chloride on the reproductive system in pubertal male rats. J. Vet. Sci. 4, 29-34.

\section{초록 : TBTCl (tri-n-butyltin chloride)과 bisphenol A에 의한 단기노출이 등줄쥐의 번식에 미치는 영향}

김지혜 ${ }^{1} \cdot$ 민병윤 $^{2} \cdot$ 윤명희 $^{1}$ *

( ${ }^{1}$ 경성대학교 생물학과, ${ }^{2}$ 경남대학교 환경공학부)

TBTCl과 bisphenol A (BPA)가 등줄쥐의 번식에 어떠한 영향을 미치는지 알아보기 위하여, 등줄쥐를 비번식기 에 포획하여 번식기 직전에 TBTCl과 $\mathrm{BPA}$ 를 근육 주사한 후, 4 개월 간 사육하였다. 그 결과, 암.수 모두 체중 증가 량에 차이가 없었고, 수컷 체내의 각 화합물의 체내 잔류량, 성체와 새끼(F1) 수컷에 대한 생식소중량지수(GSI) 및 정소와 부정소의 광학 및 전자현미경 조직상이 대조군과 별다른 차이점을 보이지 않았다. 그러나 TBTCl 투여 군에서는 출생한 태아의 사망 빈도가 높고, $\mathrm{BPA}$ 투여군에서는 유산율이 대조군에 비해서 높았다. 이로부터, 비번 식기의 성체 등줄쥐에게 $\mathrm{TBTCl}$ 과 $\mathrm{BPA}$ 를 단기간 투여했을 때, 이들 물질은 체내에 장기간 잔류하지 않으며, 성체 및 다음 세대 수컷의 생식기관에 영향을 미치지 않지만, 수태된 태아의 발생을 저해하는 물질임이 밝혀졌다. 